\title{
PENERAPAN METODE NAÏVE BAYES DALAM MEMPREDIKSI PRESTASI SISWA DI SMA NEGERI 1 PANOMBEIAN PANEI
}

\author{
Sarina Marpaung*, Solikhun, Irawan \\ Sekolah Tinggi Ilmu Komputer Stikom Tunas Bangsa \\ Jl. Sudirman, Proklamasi, Siantar Barat., Kota Pematang Siantar, Sumatera Utara \\ E-mail : * sarinamarpaung19@gmail.com
}

\begin{abstract}
ABSTRAK- Tujuan dari penelitian ini adalah untuk melakukan klasifikasi dalam menentukan prestasi siswa di SMA Negeri 1 Panombeian Panei. Untuk mengetahui hasil dari klasifikasi prestasi siswa di sekolah tersebut maka digunakan metode data mining Klasifikasi dengan Algoritma Naive Bayes. Sumberdata didapatkan dari hasil kuesioner yang diberikan kepada siswa kelas 2 semester genap, dengan sampel data 105Siswa. Atribut yang digunakan sebanyak 4, yaitu Keberadaan guru (C1), Kemampuan Siswa (C2), Motivasi(C3) dan Lingkungan Sekolah (C4). Diperoleh hasi penelitian bahwa nilai Accuracy sebesar $91.00 \%$. class precision pada prediksi kurang berprestasi memiliki nilai $83.33 \%$, sedangkan pada prediksi berprestasi memiliki nilai $93,42 \%$. Class recall pada truekurang berprestasi memiliki nilai $80.00 \%$, sedangkan pada trueberprestasi memiliki nilai 94.67 $\%$. Sehingga dengan analisis ini diharapkan dapat membantu pihak sekolah khususnya pihak pendidikan SMA Negeri 1 Panombeian Panei dalam mengetahui prestasi siswa dalam proses belajar mengajar sehingga apabila diketahui banyak siswa yang kurang berprestasi dapat dilakukan antisipasi dalam memperbaiki mutu pendidikan dalam menanganin siswa yang memiliki prestasi yang kurang sehingga dapat menghasilkan generasi yang baik dan memperbaiki kualitas sekolah.
\end{abstract}

Kata kunci : Data Mining,Algoritma Naive Bayes, Prestasi Siswa.

\section{PENDAHULUAN}

Pendidikan merupakan salah satu upaya yang dilakukan untuk menjadi penentu keberhasilan suatu bangsa, pendidikan yang berhasil akan terus menerus menghasilkan generasi yang baik pula. Seiring dengan derasnya tantangan global, tantangan dunia pendidikan menjadi semakin besar, aspek ini yang mendorong para peserta didik untuk meraih prestasi terbaik [1]. Prestasi belajar merupakan kemampuan siswa untuk belajar, yakni dengan mengingat fakta dan mengkomunikasikan pengetahuannya baik secara lisan maupun tertulis, bahkan dalam kondisi ujian. Jadi, pada intinya prestasi belajar dapat dikatakan sebagai hasil yang diperoleh dari kegiatan pembelajaran di sekolah yang bersifat kognitif dan biasanya ditentukan melalui pengukuran dan penilaian. Prestasi belajar dapat ditunjukkan melalui nilai yang diberikan oleh seorang guru dari jumlah bidang studi yang telah dipelajari oleh peserta didik. Setiap kegiatan pembelajaran tentunya selalumengharapkan akan menghasilkan pembelajaran yang maksimal. Dalam proses pencapaiannya, prestasi belajar sangat dipengaruhi oleh berbagai faktor. Salah satu faktor utama yang sangat berpengaruh dalam keberhasilan pembelajaran adalah keberadaan guru. Mengingat keberadaan guru dalam proses kegiatan belajar mengajar sangat berpengaruh, maka sudah semestinya kualitas guru harus diperhatikan [2].

Permasalahan yang sering terjadi di setiap sekolah khususnya di SMA Negeri 1 Panombeian Panei yaitu banyak ditemukan siswa yang malas belajar, siswa yang kurang menyenangin pelajaran, tidak mempunyai perhatian terhadap apa yang telah dipelajarin, tugas sekolah dijadikan beban, hasil belajar hanya untuk naik kelas atau lulus dari sekolah dan sekolah hanya sekedar bertemu teman serta mendapatkan uang jajan[3]. Semua itu merupakan gambaran dari aktifitas belajar siswa yang rendah. Sebagai akibatnya mereka mengalami kesulitan belajar. Sehingga banyak siswa yang memiliki prestasi yang berbeda-beda [4]. Di setiap sekolah khususnya di SMA Negeri 1 Panombeian Panei terdapat siswa-siswi yang memiliki prestasi tinggi atau berprestasi dan kurang berprestasi. Sehingga pihak sekolah harus melakukan antisipasi dalam memperbaiki mutu pendidikan dalam menanganin siswa yang memiliki prestasi yang kurang sehingga dapat menghasilkan generasi yang baik dan memperbaiki kualitas sekolah tersebut. Oleh sebab itu untuk memprediksi prestasi siswa yang berbeda-beda tersebut pihak pendidikan SMA Negeri 1 Panombeaian Panei memerlukan data yang akurat mengenai prestasi siswa sehingga dapat menjadi acuan untuk pihak pendidikan agar lebih mengetahui prestasi siswayang berprestasi dan kurang berprestasi. Sehingga dari permasalahan itu penulis berencana menyelesaikan permasalahan tersebut dengan menggunakan metode data mining [5].

Data mining adalah salah satu cabang ilmu kecerdasan buatan dalam penggalian pola-pola untuk mengubah data menjadi informasi. Data mining merupakan proses yang mempekerjakan satu atau lebih teknik pembelajaran computer untuk menganalisa dan mengekstraksi pengetahuan (knowladge) secara otomatis [6]. Data miningmampu mengolah data dengan jumlah yang 
besar dan dapat melakukan pencarian data secara otomatis, oleh karena itu data miningmemiliki peranan yang sangat penting dalam beberapa bidang kehidupan diantaranya yaitu bidang industri, keuangan, cuaca, ilmu dan teknologi [7].

Tugas utama pada data miningdiantaranya yaitu klasifikasi yang merupakan suatu teknik dengan melihat pada kelakuan dan atribut dari kelompok yang telah didefinisikan. Salah satu algoritma dalam klasifikasi yaitu algoritma Naive Bayes [8]. Dalam hal ini penulis menggunakan algoritma NaiveBayes dalam melakukan prediksi terhadap prestasi siswa di SMA Negeri 1 Panombeian Paneidengan tujuan untuk menentukan apakah siswa memiliki prestasi meningkat, menurun atau tetap.Variabel yang digunakan yaitu keberadaan guru, kemampuan siswa, motivasi dan lingkungan sekolah [9].

Naive Bayes adalah algoritma yang sederhana dan tiap-tiap atribut bersifat bebas, yang memungkinkan tiap atribut dapat berkontribusi terhadap hasil akhir. Teorema Bayes dikombinasikan dengan "Naive" yang berarti setiap atribut/variabel bersifat bebas. Naive Bayes memiliki akurasi dan kecepatan yang tinggi saat diaplikasikan pada database dengan data yang besar [10].

Dalam beberapa penelitian yang telah dilakukan oleh peneliti terkait metodedata miningmenggunakan algoritma Naive Bayes: [11] menjelaskan tentang algoritma Naive Bayes yang digunakan dalam memprediksi konsentrasi siswa dengan hasil perhitungan algoritma Naive Bayes memanfaatkan data training untuk menghasilkan probabilitas setiap kriteria untuk class yang berbeda, sehingga nilai-nilai probabilitas dari kriteria tersebut dapat dioptimalkan untuk memprediksi konsentrasi siswa berdasarkan proses klasifikasi yang dilakukan oleh metode Naive Bayes itu sendiri. Peneliti lain juga melakukan penelitian terkait prediksi prestasi siswa dengan metode Naive Bayes dan C4.5 [12] menjelaskan tentang algoritma $\mathrm{C} 4.5$ dan Naive Bayes yang digunakan dalam menganalisis kinerja dua metode untuk memprediksi prestasi siswa sekolah menengahkejuruan dimana evaluasi model pohon keputusan C4.5 sebagai algoritma terpilihdanNä̈ve Bayes untuk mengetahui algoritma yang memiliki keakuratan lebih tinggi dalam memprediksi prestasi siswa [13].

Berdasarkan latar belakang masalah di atas, penulis mengambil judul skripsi "Penerapan Metode Naive Bayes Dalam Memprediksi Prestasi Siswa Di SMA Negeri 1 Panombeian Panei". Diharapkan penelitian ini dapat membantu pihak sekolah dalam memprediksi prestasi siswa sehingga dapat dilakukan antisipasi dalam menangani prestasi siswa-siswa di sekolahnya. Penelitian ini juga diharapkan dapat menjadi referensi bagi peneliti selanjutnya yang berkaitan dengan pengguna algoritma yang digunakan.

\section{ISI PENELITIAN}

Hasil percobaan yang digunakan dalam penelitian ini yaitu menggunakan 2 tahap. Yaitu Tahap uji Kevalidan data dengan menggunakan SPSS dan Tahap Pengujian untuk menentukan nilai dari masing-masing klasifikasi dengan menggunakan Software Rapidminer Versi 5.3. Berikut tahapan-tahapan hasil percobaan dalam penelitian ini.

\subsection{SPSS}

1. Reliability Statistics Data

Dalam pengujian data sampel yang digunakan terdiri dari 100 data.100 data tersebut menghasilkan Reliabilitas statistic yang dapat dilihat pada gambar 1. berikut.

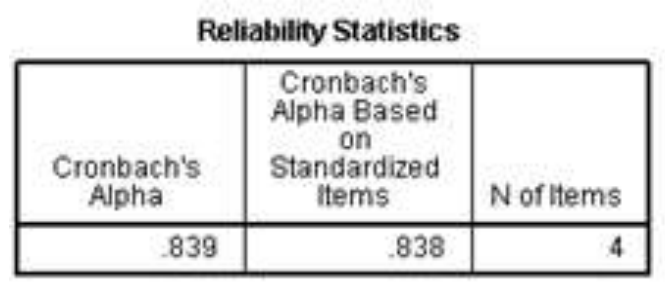

Gambar 1. Reliability Statistics Data

Pada gambar 1. analisa signifikan dan reliabilitas statistik data dapat disimpulkan bahwa nilai Cronbach's Alpha 0,839 dengan jumlah kriteria sebanyak 4 kriteria. Berdasarkan nilai Cronbach's Alpha di atas nilai standar adalah 0,838 sehingga berada diatas 0,60 (valid) dan data tersebut dapat digunakan.

\section{Validitas dan Reabilitas (Keakuratan Data)}

Keakuratan instrumen digunakan untuk mengukur secara konsisten setiap waktu dan populasi. Survei dalam studi ini diuji dalam jangka waktu dan ukuran internal yang terpercaya yang memiliki keterkaitan antara bagian bagian tes. Hal ini menjamin apakah pengukuran instrumen secara akurat dimaksudkan untuk mengukur. Cronbach's Alpha diberikan survei untuk mengukur konsistensi internal. Menurut [14 - 16], Cronbach's Alpha pada atau di atas 0.60 diterima sebagai bukti realibilitas internal. Validitas dan Realibilitasdari kuesioner dengan jumlah data sebanyak 100 item, seperti pada Tabel 2.

Tabel 2. Statistik Reliabilitas Data

\begin{tabular}{|c|l|l|c|}
\hline No. & $\begin{array}{c}\text { Variabel dalam } \\
\text { Skala }\end{array}$ & $\begin{array}{c}\text { Cronbach's } \\
\text { Alpha }\end{array}$ & $\begin{array}{c}\text { Jumlah } \\
\text { Data }\end{array}$ \\
\hline 1. & Keberadaan Guru & .841 & 100 \\
\hline 2. & $\begin{array}{l}\text { Kemampuan } \\
\text { Siswa }\end{array}$ & .801 & 100 \\
\hline 3. & Motivasi & .734 & 100 \\
\hline 4. & $\begin{array}{l}\text { Lingkungan } \\
\text { Sekolah }\end{array}$ & .756 & 100 \\
\hline
\end{tabular}


Dari Tabel di atas Cronbach's alpha dari ke empat variabel memiliki nilai di atas 0.7 ini menunjukkan bahwa data yang diolah adalah valid dan dipercaya sehingga dapat diuji coba di dalam Rapidminer.

\section{Rapid Miner}

RapidMiner digunakan untuk melakukan pengujian terhadap data yang telah didapatkan dari siswa-siswi yang menjawab kuesioner yang telah diberikan. Model aturan yang digunakan dalam rapidminer adalah algoritma Naive Bayes. Dalam mengetahui prestasi siswa penulis akan menampilkan gambaran model aturan dalam memprediksiprestasi siswa menggunakan algoritma Naive Bayes.

\section{Dataset Penelitian}

Dataset yang digunakan dalam penelitian yaitu data yang didapatkan dari dari siswa yang menjawab kuesioner, kemudian data tersebut diolah menjadi data training dan data testing. Data training yang digunakan terdapat 100 data sedangkan data testing terdapat 5 data yang digunakan. Kriteria data yang telah ditentukan dianalisis menggunakan perangkat lunak RapidMiner data Kuesioner yang akan dianalisis memiliki 105 data yang disajikan pada Tabel 1 .

\section{5. Мепи}

Berikut akan dijelaskan bagian dari menu awal pada tools RapidMiner seperti tampilan awal dari RapidMinerdan akan dimulai dengan menu newprocess.

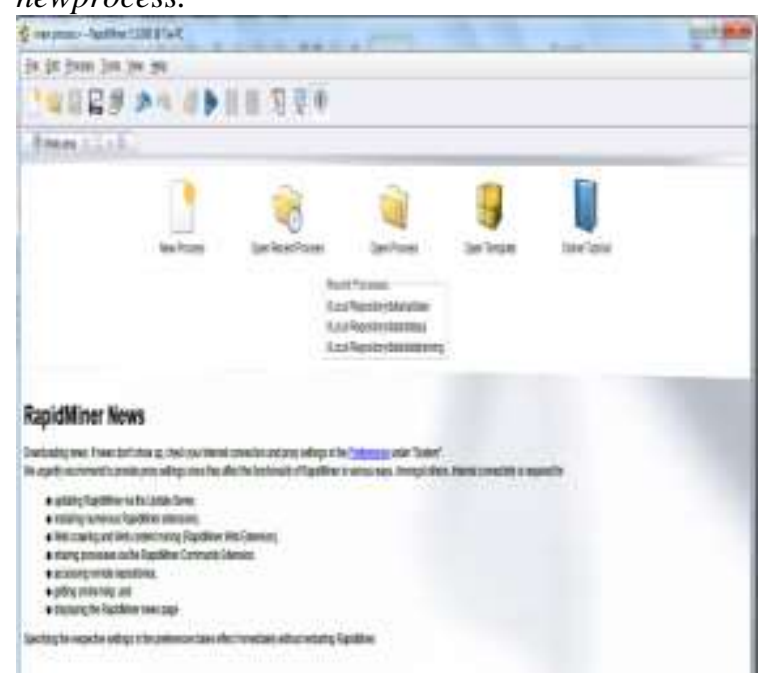

Gambar 2. Tampilan Awal Rapidminer

Pada tampilan berikut terdapat beberapa menu pilihan seperti New Process, Open Recent Process, Open Process, Open Template dan Online Tutorial. Penjelasan dari menu diatas adalah sebagai berikut :

1. New Process Menu ini berisikan tampilan awal jika kita akan membuat proses baru dengan data baru yang belum pernah ada dalam tools ini.
2. Open Recent Process Berfungsi untuk menampilkan dan membuka proses yang baru saja dibuat dengan jangka waktu tertentu, biasanya akan langsung muncul pada tampilan awal tools tanpa harus mencari pada penyimpanan lokal.

3. Open Process Menu ini berfugsi untuk membuka proses yang telah dibuat sebelumnya yang telah kita simpang di penyimpanan lokal.

4. Open Template Menu ini berisikan pilihanpilihan proses lain yang telah disediakan oleh tools rapidminer.

5. Online Tutorial Menu ini digunakan untuk memulai tutorial atau tahapan secara online.Tutorial berfungsi untuk memberikan pengenalan dan beberapa Konsep Data Mining.

Dikarenakan data yang akan diuji adalah
data Process. Maka akan muncul jendela seperti gambar berikut :

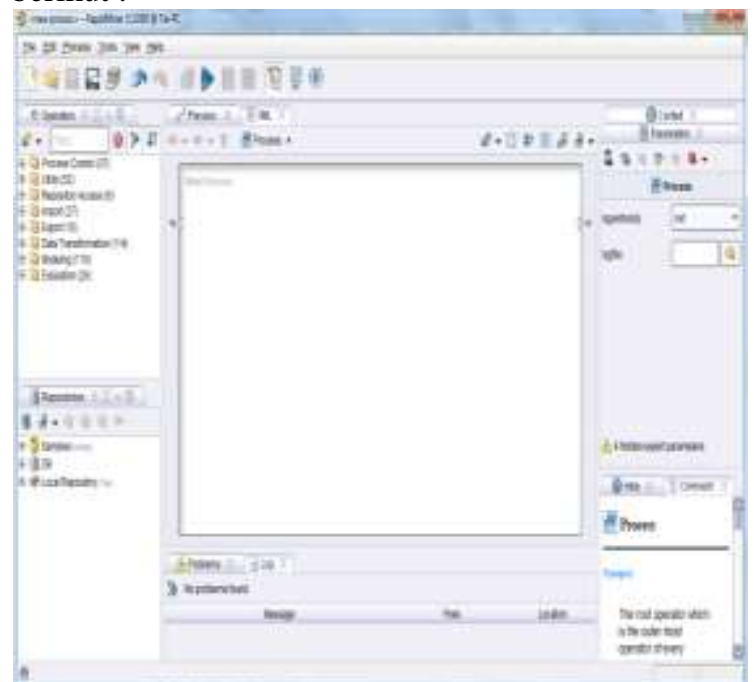

Gambar 3. New Process untuk Import Data Excel

\section{Masukan (Input)}

Sistem Menjelaskan cara memasukkan data baru yang akan dieksekusi lebih lanjut, pada hal ini data yang akan di eksekusi berupa data excel. Tahapan dapat dilihat pada gambar dibawah ini.

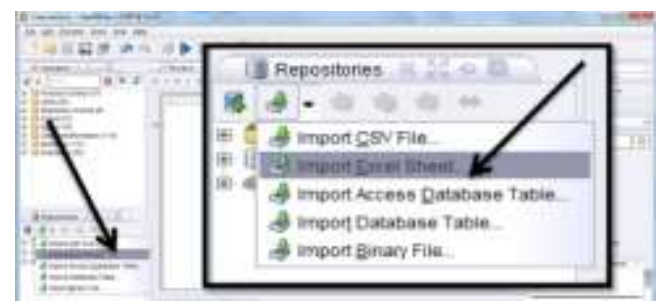

Gambar 4. Input Data Excel

Klik pada bagian kiri bawah tabel repositories lalu pilih "Import Excel Sheet". Kemudian akan muncul tampilan sperti gambar 5. 


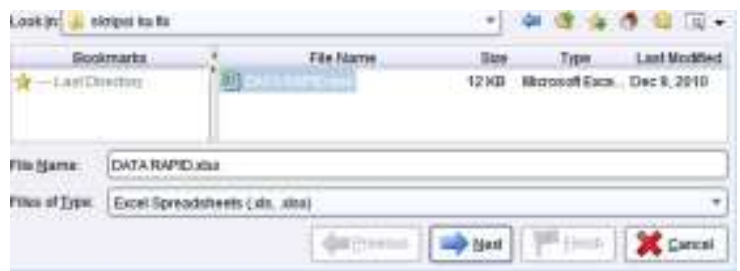

Gambar 5. Tampilan Data Import Tahap 1

Pada data import wizard kemudian pilih tempat kita menyimpan data yang akan digunakan, tampak seperti tanda panah nomor 1. Selanjutnya pilih file name data yang digunakan, tampak pada tanda panah nomor 2. Kemudian klik next pada bagian kanan bawah tanda panah nomor 3 .

Selanjutnya akan muncul tampilan seperti gambar berikut :

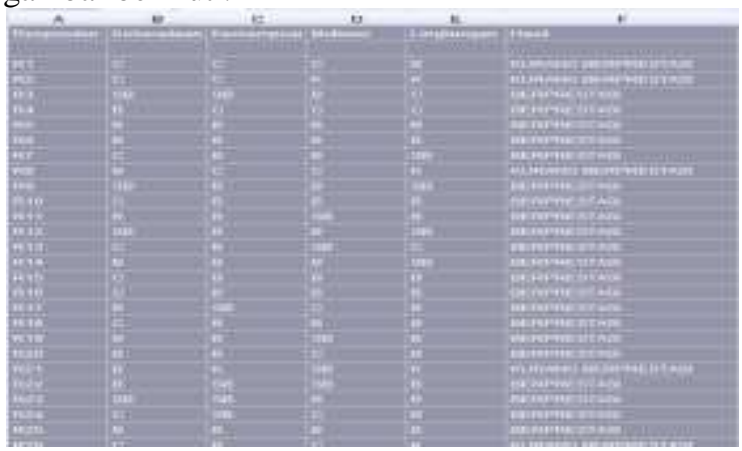

Gambar 6. Data Import Tahap 2

Gambar diatas menunjukkan isi data yang akan di proses. Pilih sheet pada data serta blok data yang akan di proses. Setelah itu akan muncul tampilan data pada gambar 7 .

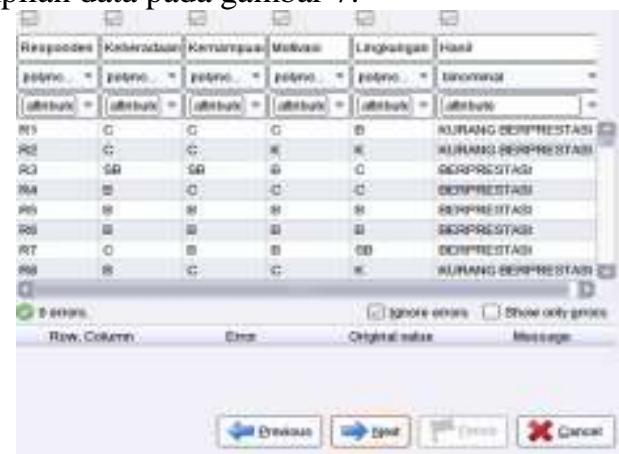

Gambar 7. Data Import Tahap 3

Pada tahap 3 dilakukan pemilihan tipe data dimana pada bagian responden atribute diubah menjadi tipe "id" dan hasil diberi tipe "label". Lalu pilih next.

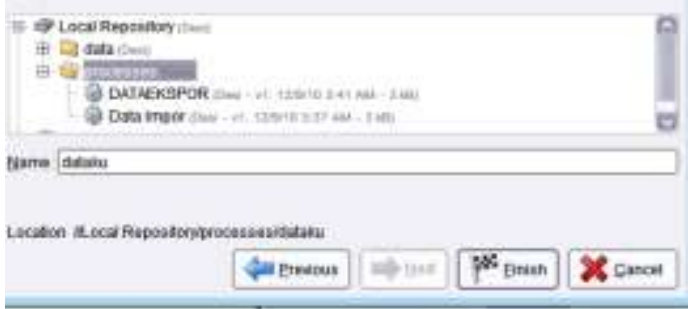

Gambar 8. Data Import Tahap 4
Pilih tempat penyimpanan data yang akan di proses kemudian tentukan nama data yang akan di proses. Selanjutnya pilih finish. Data yang telah di import akan tampak seperti gambar 9 dan data siap untuk di proses.

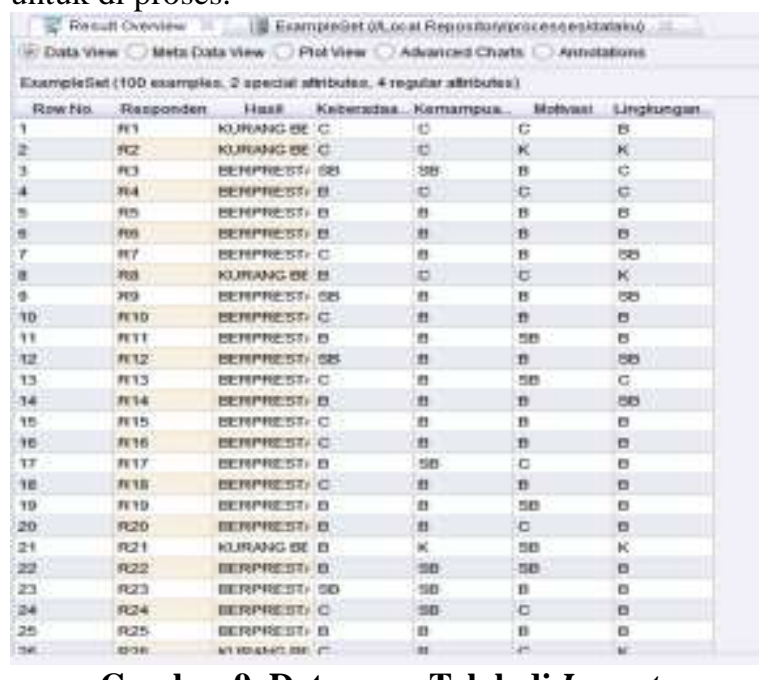

Gambar 9. Data yang Telah di Import

\section{Pemprosesan Sistem}

Pada tahap ini akan dijelaskan tahapantahapan proses pembentukan keputusan dari data yang telah di import. Seperti pada gambar $\mathbf{1 0 .}$ berikut

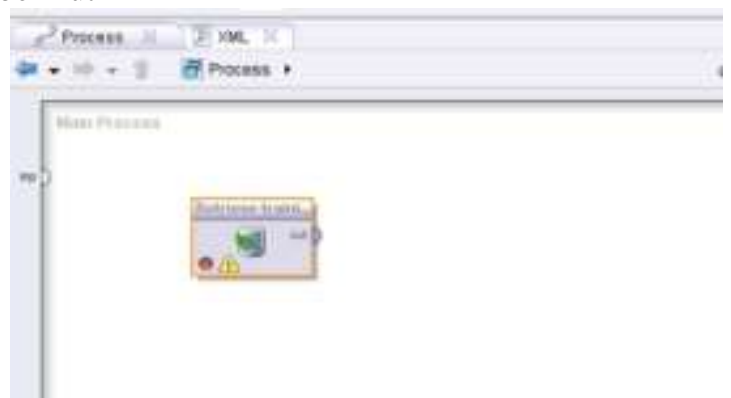

Gambar 10. Pemrosesan Data Tahap 1

Drag atau klik dan tahan data training yang telah diimport pada repositories ke lembar kerja main process seperti pada gambar 10. Untuk membentuk keputusan, data perlu dihubungkan oleh operator Naive Bayes. Pada bagian filter ketikkan naive bayes untuk menambahkan operator naive bayes pada lembar kerjamain process. Langkah berikutnya drag dan drop operator Naive Bayes lalu hubungkan pada output seperti yang tertera pada gambar 11 .

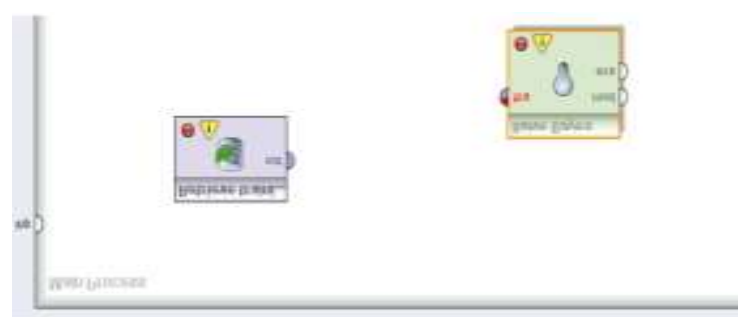

Gambar 11. Pemrosesan Data Tahap 2 


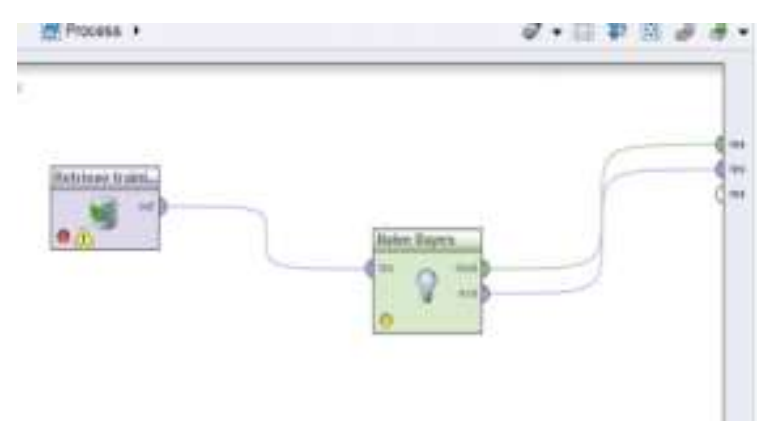

Gambar 12. Pemrosesan Data Training Tahap 3

Data yang telah dihubungkan dengan operator Nä̈ve Bayes maka langkah selanjutnya adalah melihat pada lembar main proses operator Nä̈ve Bayes tidak terdapat tanda error. Apabila masih terdapat kesalahan, kemungkinan data yang yang di input tidak valid atau tidak dapat diproses dikarenakan masih terdapat data yang tidak cocok. Dan jika pada data dan operator Nä̈ve Bayes sudah tidak terdapat tanda error maka pemrosesan data dapat dilanjutkan untuk medapatkan hasil yang diinginkan. Maka pemrosesan data berakhir pada tahap kedua.

\section{Keluaran (Output) Sistem}

Untuk mendapatkan hasil berupa pohon keputusan maka pada tahap selanjutnya dapat dilakukan dengan cara mengklik tanda panah biru (Run) yang terdapat diposisi tengah atas pada bagian toolbar. Pada tahap ini akan menampilkan hasil akhir serta langkah terakhir dalam penggunaan tools Rapidminer ini. Hasil akhir yang akan ditampilkan adalah berupa SimpleDistrubition yaitu menentukan banyaknya nilai dari data Berprestasi dan kurang Berprestasi. Dapat dilihat pada gambar 13.

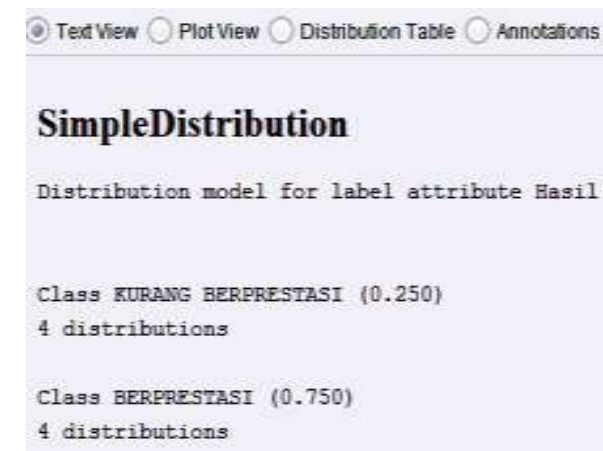

\section{Gambar 13. Hasil Akhir}

Berdasarkan gambar 12. menjelaskan bahwa kelas berprestasi memiliki nilai klasifikasi/probabilitas 0,750 sedangkan kelas kurang berprestasi mendapatkan nilai klasifikasi/probabilitas 0,250.Sehingga berdasarkan data hasil klasifikasi pada gambar 13. didapatkan grafik hasil dari RapidMiner berikut ini :

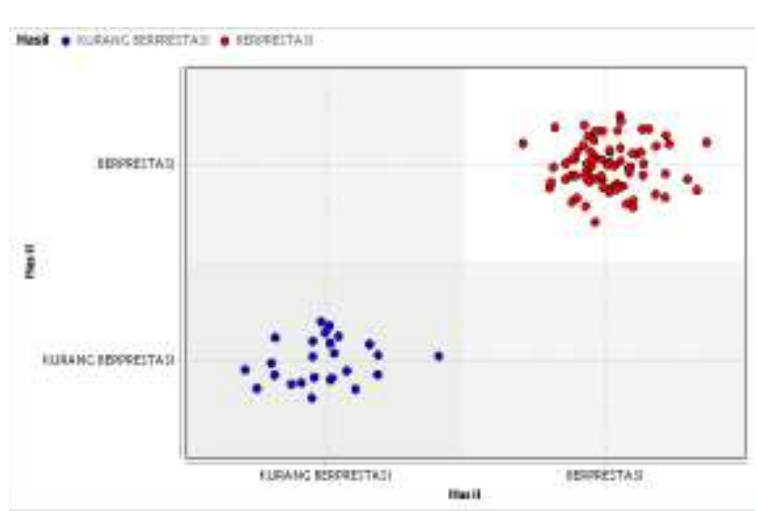

Gambar 14. Grafik klasifikasi

Berdasarkan pada gambar 14. dapat diketahui bahwa pada titik berwarna merah (Berprestasi) memiliki node sebanyak75, sedangkan pada titik berwarna biru (kurang berprestasi) memiliki node sebanyak 25.

Akurasi Hasil pengujian Model Algoritma Naive Bayes Classfier ditunjukan pada gambar berikut:

\begin{tabular}{|c|c|c|c|}
\hline \multicolumn{4}{|c|}{ 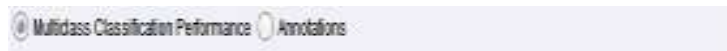 } \\
\hline \multicolumn{4}{|l|}{ G Table Ven OPdWas } \\
\hline \multicolumn{4}{|c|}{ 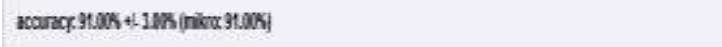 } \\
\hline & WEWRYG EERYPESTLSI & ha aERPPESTIS: & dass peosing \\
\hline ped KRAVS ECGPRESTIS & 20 & 4 & $3333 \%$ \\
\hline ped BEpPGESTIS & 5 & 71 & $93<8$ \\
\hline dassinal & $800 \%$ & $5457 \%$ & \\
\hline
\end{tabular}

\section{Gambar 15 Nilai Accuracy Performance}

Keterangan :

1. Jumlah prediksi kurang berprestasi dan kenyataannya benar kurang berprestasi adalah 20 record $(\mathrm{FN})$.

2. Jumlah prediksi berprestasi dan kenyataannya benar kurang berprestasi adalah 5record $(\mathrm{TN})$.

3. Jumlah prediksi kurang berprestasi dan kenyataannya benar berprestasi adalah 4record (FP).

4. Jumlah prediksi berprestasi dan kenyataannya benar berprestasi adalah 71 record (TP).

Pada gambar 14. Nilai Accuracy sebesar $91.00 \%$. class precision pada prediksi kurang berprestasi memiliki nilai $83 . .33 \%$, sedangkan pada prediksi berprestasi memiliki nilai $93,42 \%$. Class recall pada truekurang berprestasi memiliki nilai $80.00 \%$, sedangkan pada trueberprestasi memiliki nilai $94.67 \%$.

\section{KESIMPULAN}

Berdasarkan hasil penelitian dan pembahasan yang telah dilakukan, dapat disimpulkan bahwa algoritma Naive Bayesian Classification (NBC) dapat digunakan sebagai salah satu metode untuk klasifikasi dalam memprediksiprestasi siswa di SMA $\quad$ N 1 
Panombeian Panei dengan parameter yang digunakan dalam penelitian ini yaitu keberadaan guru, kemampuan siswa, motivasi dan lingkungan sekolah. Berdasarkan 100 data training yang diolah di dalam Rapidminer, hasil pengujian menunjukkan akurasi sebesar $91.00 \%$ yaitu 25 responden dinyatakan kelas kurang berprestasi dan 75 responden dinyatakan memiliki kelas berprestasi. Denganclass precision pada prediksi kurang berprestasi memiliki nilai $83.33 \%$, sedangkan pada prediksi berprestasi memiliki nilai 93,42\%. Class recall pada true kurang berprestasi memiliki nilai $80.00 \%$, sedangkan pada true berprestasi memiliki nilai $94.67 \%$. Sehingga kesimpulan yang didapatkan bahwa nilai siswa berprestasi lebih besar daripada nilai siswa kurang berprestasi.

\section{PENUTUP}

4 (Empat) variabel yang digunakan saat ini sudah cukup baik, tetapi jumlah variabel sebaiknya ditambah untuk meningkatkan akurasi hasil prediksi. Variabel yang ditambah tentu yang memiliki dampak atas prestasi siswa.

\section{DAFTAR PUSTAKA}

[1] Izzaty, R. E., Ayriza, Y. \& Setiawati, F. A. (2017) Prediktor Prestasi Belajar Siswa Kelas 1 Sekolah Dasar, 44, pp. 153-164. doi: 10.22146/jpsi.27454.

[2] Sari, D. R. et al. (2019) Penerapan Metode Naive Bayes dalam Memprediksi Kepuasan Mahasiswa Terhadap Cara Pengajaran Dosen, Prosidiing Seminar Nasional Riset Information Science (SENARIS), pp. 287297. doi: 10.30645/senaris.v1i0.34.

[3] Yunita, D., Amalia, R. \& Rosyani, P. (2018) Analisa Prestasi Siswa Berdasarkan Kedisiplinan, Nilai Hasil Belajar , Sosial Ekonomi dan Aktivitas Organisasi Menggunakan Algoritma Naïve Bayes, 3(4), pp. 2-5.

[4] Saleh, A. (2015) Klasifikasi Metode Naive Bayes Dalam Data Mining Untuk Menentukan Konsentrasi Siswa (Studi Kasus Di Mas Pab 2 Medan), KeTIK, pp. 200-208.

[5] Noviriandini, A. \& Nurajijah (2019) Analisis kinerja algoritma c4.5 dan naïve bayes untuk memprediksi prestasi siswa sekolah menengah kejuruan, jurnal Ilmu Pengetahuan Dan teknologi, 5(1), pp. 23-28.

[6] Miratama, H. (2016) Prediksi Prestasi Mahasiswa dengan Jalur Siswa Berprestasi ( PSB ) Menggunakan Metode Naïve Bayers, 15(1), pp. 44-50.

[7] Erlangga, N., Solikhun \& Irawan (2019) Penerapan Data Mining Dalam Mengelompokan Produksi Jagung Menurut
Provinsi Menggunakan Algoritma K-Means, KOMIK, 3, pp. 702-709. doi: 10.30865/komik.v3i1.1681.

[8] Handayani, F. \& Pribadi, S. (2015) Implementasi Algoritma Naive Bayes Classifier dalam Pengklasifikasian Teks Otomatis Pengaduan dan Pelaporan Masyarakat melalui Layanan Call Center 110, Jurnal Teknik Elektro Vol., 7(1).

[9] Imandasari, T. I. A. (2019) Algoritma Naive Bayes Dalam Klasifikasi Lokasi Pembangunan Sumber Air.

[10] Purnomo, R. A. (2016) Analisis Statistik Ekonomi dan Bisnis Dengan SPSS. 1st edn. CV.WADE GROUP.

[11] Luvia, Y. S., Hartama, D. \& Solikhun (2016) Penerapan Algoritma C4.5 Untuk Klasifikasi Predikat Keberhasilan Mahasiswa Di Amik Tunas Bangsa, Jurasik, 1.

[12] Malik, K. \& Faid, M. (2016) Prediksi prestasi siswa smp nurul jadid menggunakan algoritma c4.5, Nusantara Journal of Computers and its Applications Volume, 2(4), pp. 2-5.

[13] Mayangsari, D. R. S., Solikhun \& Irawan (2019) Pengelompokkan Jumlah Desa / Kelurahan Yang Memiliki Dengan Menggunakan Metode K-Means Cluster, KOMIK, 3, pp. 370-377. doi: 10.30865/komik.v3i1.1615.

[14] Sabna, E. \& Muhardi (2016) Penerapan Data Mining Untuk Memprediksi Prestasi Akademik Mahasiswa Berdasarkan Dosen , Motivasi , Kedisiplinan, Ekonomi dan Hasil Belajar, Jurnal CoreIT, 2(2), pp. 41-44.

[15] E. Indra et al., "Design and Implementation of Student Attendance System Based on Face Recognition by Haar-Like Features Methods," in 2020 3rd International Conference on Mechanical, Electronics, Computer, and Industrial Technology (MECnIT), 2020, pp. 336-342.

[16] E. Indra, K. Ho, Arlinanda, R. Hakim, D. Sitanggang, and O. Sihombing, "Application of C4.5 Algorithm for Cattle Disease Classification," in Journal of Physics: Conference Series, 2019, vol. 1230, no. 1. 